\title{
Synthesized Two New Water-soluble Fluorescents Calix[4]arene 4-sulfo-1,8-naphthalimide Derivatives Inhibit Proliferation of Human Colorectal Carcinoma Cells
}

\author{
Ayse Yildirim \\ Selcuk University \\ Serdar Karakurt \\ Selcuk University: Selcuk Universitesi \\ Mustafa Yilmaz ( $\square$ myilmaz42@yahoo.com ) \\ Selçuk University https://orcid.org/0000-0003-2904-160X
}

\section{Research Article}

Keywords: anticancer agent, calixarene, naphthalimide, cytotoxicity

Posted Date: May 19th, 2021

DOl: https://doi.org/10.21203/rs.3.rs-507211/v1

License: (c) (i) This work is licensed under a Creative Commons Attribution 4.0 International License.

Read Full License 


\section{Abstract}

Synthesis of 1,8-naphthalimide derivatives and biochemical studies using them as anti-cancer and cellular imaging agents have attracted significant attention in recent years. This study aimed to synthesize two new fluorescent lower rim-functionalized 4-sulfo-1,8-naphthalimide derivatives of calix[4]arenes [4 and 7] and examination of their cytotoxic properties for cancerous cells. For this purpose, $p$-tert-butylcalix[4]arene bearing dihydrazide [3] or diaminopropyl [6] units on its lower rim were reacted with 4-sulfo-1,8-naphthalic anhydrate. The structure of these synthesized compounds has been characterized using ${ }^{1} \mathrm{H}-\mathrm{NMR},{ }^{13} \mathrm{C}-\mathrm{NMR}$, and FT-IR techniques. To investigate the anti-cancer properties, compounds 4, 7, and N,N-dimethylaminoethyl-1,8-naphthalimide [8] were tested on the human colorectal cancer cell line (DLD-1) as well as healthy colon epithelial cell line (CCD-18Co). The IC ${ }_{50}$ values of $\mathbf{4}$ and $\mathbf{7}$ were determined as $12.95 \mu \mathrm{M}$ and $16.13 \mu \mathrm{M}$, respectively, on DLD-1 cells. Furthermore, following the treatment of CCD-18Co cells with 4 and 7, the $\mathrm{IC}_{50}$ values were determined as $508 \mu \mathrm{M}$ and $269 \mu \mathrm{M}$, respectively. However, it was observed that compound $\mathbf{8}$ had no cytotoxic effect on both DLD-1 cells and CCD-18Co cells. Furthermore, the fluorescence imaging of human colorectal cancer cells treated with the synthesized compounds $[\mathbf{4}, 7$, and $\mathbf{8}]$ was performed on living cells.

\section{Introduction}

Cancer, one of the most important and dangerous diseases worldwide, possesses a high mortality rate due to lifestyle change and global population aging $(9,47)$. World Health Organization reported that 9.6 million died in 2018 due to cancer, and this number would reach 15 million by $2030(38,24)$. Colon cancer ranks third, with a rate of $10 \%$ among cancer types worldwide (16). Colon cancer occurs with the formation of malignant and adenomatous cells in the colon (6). Chemotherapy has an important place in cancer treatment; however, its importance in treating and regressing different cancer types should not be ignored (12). The disadvantage of drugs used in cancer chemotherapy is that they are not selective. The main problem in cancer treatment is severe side effects for chemotherapotical medicines due to miss targeting $(1,27)$. The high metabolite consumption rate of cancerous cells and increased signaling pathways make cancerous cells more resistant to many anticarcinogenic agents (32). Herein, developing new anti-cancer agents gain crucial importance to decrease the high mortality rate of cancer (26).

Calix[n]arenes, which are cyclic and flexible compounds, are easily synthesized in large quantities by the base-catalyzed condensation reaction between formaldehyde and $p$-tert-butyl-phenol $(23,46)$. Calixarenes have significant advantages over other macrocyclic compounds, such as synthetic versatility on both the lower and upper edges, a hydrophobic cavity, and being able to be decorated with a flexible and welldefined binding core. Calix[n]arene skeleton can have both hydrophilic and hydrophobic features simultaneously from the same molecule (36). They may interact with nucleic acids (25) and proteins (22), which modulate the activity of cancerous cells, metabolic pathways, and many enzymes $(40,39)$. The preferred calixarenes in the design of novel drugs have multiple structural properties. Recently, calix[n]arenes have been used as anti-cancer agents in molecular scaffolds or building blocks and biochemical studies due to their limited toxicity $(7,40,39,4,2,3,21,51)$. 
Ding et al. synthesized calix[n]arene functionalized with 2-dimethylaminoethyl groups on their lower rims and reported that the calix[4]arene inhibits the proliferation of several drug-resistant tumor cells (18). In another study, calix[4]arenes were functionalized with polyhydroxyamine, and their cytotoxic effects were investigated in different cancer cells. The results exhibited that the calix[4]arene is quite effective in human ovarian carcinoma cells (36). Recently, L- or D-proline derivatives of calix[4]arene have been used against human cervical cancer, and it was observed that L1 pentamer formation of HPV (Human papillomavirus) was inhibited by the L-proline derivative of calix[4]arene (22). In our previous study, we prepared L-proline derivatives of calix[4]arene and examined their cytotoxic properties on different human cancer cells, and clarified the cell death mechanism (37).

In this study, two new calix[4]arene 4-sulfo-1,8-naphthyl derivatives were synthesized. The imides formed as a result of the replacement of the stretched oxygen in the compound of the 1,8-naphthalimide with the primary amine compounds are essential substances for applications in the technological and biomedical fields. 1,8-naphthalimide derivatives have been used to create biological probes, supramolecular building stones, optoelectronic devices, analytical and smart materials, and fluorescent or phosphorus probes (53, $5,19,52,30,42,45,11,17,10,33,44,31,41,29)$. The substituted 1,8-naphthalimide structures have been used in both cation/anion detection, and their photophysical properties have been discussed. Besides, naphthalimides are suitable for detecting amino acids and nucleic acids, facilitating their interactions with biologically essential macromolecules $(19,33)$.

It has been known that the substituted 1,8-naphthalimide structures exhibit therapeutic properties (15). Wilson et al. confirmed that substituted 1,8-naphthalimide bearing a 3-(dimethylamino)ethyl group at the diimide site showed anti-cancer properties on various cancerous cell lines. These molecules interacted with DNA electrostatically since the tertiary amine was protonated at physiological $\mathrm{pH}$ (43).

1,8-naphthalimides were demonstrated to inhibit the proliferation of breast, human cervical, prostate, and

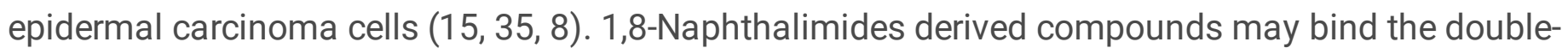
strand DNA by intercalating between adjacent base pairs and interfere with the DNA-protein interactions $(44,49,50,5)$. These derivatives might change the DNA conformation and prevent DNA duplication or transcription, thus inhibiting cancer cell growth.

There are limited literature reports on fluorescent calix[4] arene derivatives used in anti-cancer studies. In this study, two novel fluorescent calix[4]arene derivatives were formed by the interaction between 4-sulfo1,8-naphthalic anhydride and dihydrazide [3] or diaminopropyl [6] derivative of calix[4]arenes, and their cytotoxic effects for human colon cancer cell were investigated.

\section{Materials And Methods}

\section{Materials and Instruments}

The reagents used were provided by different commercial companies (Merck, Fluka, and Sigma-Aldrich) and used without further purification. The synthesized substances were followed by thin-layer 
chromatography (TLC) (Kieselgel 60 F254 (Merck)). The melting points of all solid products were measured on a Gallenkamp. ${ }^{1} \mathrm{H}-\mathrm{NMR}$ spectra were enrolled on a Varian $400 \mathrm{MHz}$ spectrometer in $\mathrm{CDCl}_{3}$ and DMSO- $\mathrm{d}_{6}$, and the vibration spectra of the compounds were recorded using a Bruker Vertex FT-IR spectrometer. The fluorescence spectra were obtained on a Perkin Elmer LS 55 spectrometer.

\section{Synthesis}

The calix[4]arene derivatives [2, 3, 5, and 6] were synthesized according to previously published methods $(34,14,13) .4,7$, and 8 were also prepared as described below.

\section{Synthesis of compound [4]}

Calix[4]arene derivative [3] $(0.3 \mathrm{~g}, 0.39 \mathrm{mmol})$ was dissolved in $10 \mathrm{~mL}$ of DMF, and $0.747 \mathrm{~g}(2.36 \mathrm{mmol})$ of 4-sulfo-1,8-naphthalic anhydride potassium salt was added into this solution and stirred for $1 \mathrm{~h}$ at RT under inert atmosphere $\left(\mathrm{N}_{2}\right)$. Then $1.5 \mathrm{~mL}$ of $25 \%$ ammonia solution was added into the solution and heated at $80^{\circ} \mathrm{C}$ for $24 \mathrm{~h}$. The reaction was followed by TLC (hexane: acetone 3:1), and after the reaction was completed, $40 \mathrm{~mL}$ of acetone and $4 \mathrm{~mL}$ of deionized water were added, and then the reaction mixture was stirred at RT for $1 \mathrm{~h}$. The precipitate formed was filtered through a filter with $0.45 \mu \mathrm{m}$ pore size (Millipore®, USA), and the solvent was evaporated in a vacuum. Finally, $\mathbf{4}$ was formed as a yellowish solid. Yield: $80 \%$ Mp > 300 C; FT-IR: $3496 \mathrm{~cm}^{-1}(\mathrm{O}-\mathrm{H}), 3196 \mathrm{~cm}^{-1}, 3093 \mathrm{~cm}^{-1}, 2955 \mathrm{~cm}^{-1}(\mathrm{C}-\mathrm{H}, \mathrm{N}-\mathrm{H}), 1673$ $\mathrm{cm}^{-1}(\mathrm{C}=0),{ }^{1} \mathrm{H}-\mathrm{NMR}\left(400 \mathrm{MHz}, \mathrm{DMSO}_{-} \mathrm{d}_{6}\right): \delta(\mathrm{ppm}): 1.1$ ( $\mathrm{s}, 18 \mathrm{H}$, But ), $1.16(\mathrm{~s}, 18 \mathrm{H}$, But ), 3.35-3.52 (m, 4H, Ar- $\left.\mathrm{CH}_{2}-\mathrm{Ar}\right), 3.9-4.32\left(\mathrm{~m}, 4 \mathrm{H}, \mathrm{Ar}-\mathrm{CH}_{2}-\mathrm{Ar}\right), 4.39-4.94\left(\mathrm{~m}, 4 \mathrm{H},-\mathrm{CH}_{2^{-}}\right), 7.09-7.16(\mathrm{br}, 8 \mathrm{H}, \mathrm{ArH}), 7.8(\mathrm{t}, 2 \mathrm{H}$, $\left.J=7.24 \mathrm{~Hz} \operatorname{ArH}_{\mathrm{Nap}}\right), 8.2\left(\mathrm{t}, 2 \mathrm{H}, J=7.43 \mathrm{~Hz}, \operatorname{ArH}_{\mathrm{Nap}}\right), 8.38-8.43\left(\mathrm{~m}, 4 \mathrm{H}, \operatorname{ArH}_{\mathrm{Nap}}\right), 9.2(\mathrm{~d}, 2 \mathrm{H}, J=1.27 \mathrm{~Hz}$ $\left.\mathrm{ArH}_{\mathrm{Nap}}\right), 11.7$ (s,2H, Amide); ${ }^{13} \mathrm{C}-\mathrm{NMR}(400 \mathrm{MHz}$ DMSO-d 6 ) $\delta$ (ppm): 164.8, 164.3, 150.3, 134.6, 130.2, 129.8, 128.3, 127.1, 125.4, 123.6, 122.9, 31.8, 31.3. Anal. Calc.: $\mathrm{C}_{72} \mathrm{H}_{70} \mathrm{~K}_{2} \mathrm{~N}_{4} \mathrm{O}_{16} \mathrm{~S}_{2} .4 \mathrm{H}_{2} \mathrm{O}$. C, 59.16; $\mathrm{H}, 5.38$; K, 5.35; N, 3.83; S, 4.39\%. Found: C, 59.10; H, 5.31; K, 5.30; N, 3.75; S, 4.31\%.

\section{Synthesis of compound [7]}

Compound 6 ( $0.3 \mathrm{~g}, 0.39 \mathrm{mmol})$ was dissolved in $10 \mathrm{~mL}$ of DMF, and $0.747 \mathrm{gram}$ ( $2.36 \mathrm{mmol})$ of 4-sulfo1,8-naphthalic anhydride potassium salt was added into this solution and stirred at RT for $1 \mathrm{~h}$ at RT under $\mathrm{N}_{2}$. Then $1.5 \mathrm{~mL}$ of $25 \%$ ammonia solution was added to the solution and heated at $80^{\circ} \mathrm{C}$ for $24 \mathrm{~h}$. The reaction was monitored by TLC (hexane: acetone 1:1), and at the end of the reaction, the mixture was added dropwise into a mixture of $100 \mathrm{~mL}$ of acetone and $3 \mathrm{~mL}$ of deionized water. The mixture was stirred for $1 \mathrm{~h}$ at RT. The precipitate was filtered through a filter with $0.45 \mu \mathrm{m}$ pore size (Millipore ${ }^{\circledR}, \mathrm{USA}$ ), and the resulting clear yellowish solution was evaporated in a vacuum. The target compound 7 was formed as a yellow solid. Yield: 85\%. Mp > $300^{0} \mathrm{C}$; FT-IR: $3330 \mathrm{~cm}^{-1}, 3045 \mathrm{~cm}^{-1} 2955 \mathrm{~cm}^{-1}(\mathrm{O}-\mathrm{H}, \mathrm{N}-\mathrm{H}, \mathrm{C}-\mathrm{H})$ $1670 \mathrm{~cm}^{-1}(\mathrm{C}=0) .{ }^{1} \mathrm{H}-\mathrm{NMR}\left(400 \mathrm{MHz}, \mathrm{DMSO}-\mathrm{d}_{6}\right) \delta(\mathrm{ppm}): 1.1$ ( $\mathrm{s}, 18 \mathrm{H}$, But), 1.16 (s, 18H, But ), 2.36-2.48 (m, 4H, - $\left.\mathrm{C}-\mathrm{CH}_{2}-\mathrm{C}-\right)$, 3.39 (d, 4H, J=10.34 Hz ArCH$\left.{ }_{2} \mathrm{Ar}\right), 4.01-4.04\left(\mathrm{~m}, 4 \mathrm{H}-\mathrm{CH}_{2}-\right), 4.10-4.26\left(\mathrm{~m}, 4 \mathrm{H}, \mathrm{Ar}-\mathrm{CH}_{2}-\right.$ Ar ), $4.39\left(\mathrm{t}, 4 \mathrm{H}, J=7.43 \mathrm{~Hz}-\mathrm{CH}_{2}-\right), 7.03-7.12(\mathrm{br}, 8 \mathrm{H}, \mathrm{ArH}), 7.76-7.86\left(\mathrm{~m}, 2 \mathrm{H}, \operatorname{ArH}_{\mathrm{Nap}}\right), 8.15-8.22(\mathrm{~m}, 2 \mathrm{H}$, $\left.\mathrm{ArH}_{\mathrm{Nap}}\right), 8.36-8.62\left(\mathrm{~m}, 4 \mathrm{H}, \mathrm{ArH}_{\mathrm{Nap}}\right), 9.17-9.2\left(\mathrm{~m}, 2 \mathrm{H}, \mathrm{ArH}_{\mathrm{Nap}}\right) ;{ }^{13} \mathrm{C}-\mathrm{NMR}\left(400 \mathrm{MHz} \mathrm{DMSO}-\mathrm{d}_{6}\right) \delta(\mathrm{ppm})$ : 
164.2, 150.7, 150.5, 134.6, 133.7, 130.5, 128.7, 126.1,125.3, 123.4,122.5, 75.4, 34.5, 31.4. Anal. Calc.: $\mathrm{C}_{74} \mathrm{H}_{76} \mathrm{~K}_{2} \mathrm{~N}_{2} \mathrm{O}_{14} \mathrm{~S}_{2} .4 \mathrm{H}_{2} \mathrm{O} . \mathrm{C}, 62.08 ; \mathrm{H}, 5.91 ; \mathrm{K}, 5.46 ; \mathrm{N}, 1.96 ; \mathrm{S}, 4.48 \%$. Found: $\mathrm{C}, 62.01 ; \mathrm{H}, 5.80 ; \mathrm{K}, 5.40 ; \mathrm{N}$, $2.00 ; \mathrm{S}, 4.40 \%$.

\section{Synthesis of Compound [8]}

$1.0 \mathrm{~g}$ (3.16 mmol) of 4-sulfo-1,8-naphthalic anhydride potassium salt was dissolved in $20 \mathrm{~mL}$ of water and stirred at RT for $1 \mathrm{~h}$. Then N,N-dimethylaminoethylamine (15.8 mmol) was added dropwise to the solution under $\mathrm{N}_{2}$, and the mixture was refluxed for $3 \mathrm{~h}$ under $\mathrm{N}_{2}$. Then the solvent was removed in a vacuum. The residue was washed with ethanol. The product was dried in a vacuum oven overnight, and the yellowish solid 8 was obtained in $75 \%$ yield. Mp $>300^{0} \mathrm{C}$; FT-IR: $1655 \mathrm{~cm}^{-1}(\mathrm{C}=0){ }^{1} \mathrm{H} \mathrm{NMR}(400 \mathrm{MHz}$, DMSO-d 6 ) $\delta(\mathrm{ppm}): 2.24\left(\mathrm{~s}, 6 \mathrm{H},-\mathrm{N}\left(\mathrm{CH}_{3}\right)_{2}\right), 2.55\left(\mathrm{t}, 2 \mathrm{H}, J=6.74 \mathrm{~Hz}-\mathrm{CH}_{2}-\right) 4.15\left(\mathrm{t}, 2 \mathrm{H}, J=5.8 \mathrm{~Hz}^{-} \mathrm{CH}_{2}-\mathrm{N}\right)$, 7.82-7.90 (m, 1H, ArH), $8.22(\mathrm{~d}, 1 \mathrm{H}, \mathrm{J}=7.65 \mathrm{~Hz} A r H), 8.44-8.49(\mathrm{~m}, 2 \mathrm{H}, A r H), 9.2(\mathrm{~d}, 1 \mathrm{H}, J=8.83 \mathrm{~Hz}$ ArH); ${ }^{13} \mathrm{C}-\mathrm{NMR}\left(400 \mathrm{MHz}, \mathrm{DMSO}-\mathrm{d}_{6}\right) \delta$ (ppm): 164.2, 163.5, 150.2, 134.6, 131.2, 130.7, 128.6, 128.1, 127.3, 125.5, 123.2, 122.5, 56.7, 45.8, 37.8. Anal. Calc.: $\mathrm{C}_{16} \mathrm{H}_{15} \mathrm{KN}_{2} \mathrm{O}_{5} \mathrm{~S}$. C, 49.73; H, 3.91; K, 10.12; N, 7.25; S, 8.30\%. Found: C,49.77; H, 3.82; K, 10.10; S, 8.32\%.

\section{Analysis of Fluorescence $[4,7$, and 8]}

The stock solutions $\left(1 \times 10^{-2} \mathrm{M}\right)$ were prepared from the compound $[\mathbf{4}, \mathbf{7}$, or $\mathbf{8}]$, and the stock solution was diluted to $1 \times 10^{-5} \mathrm{M}$. The spectrophotometric measurements were in a mixture of DMSO/EtOH (1:100 $\mathrm{v} / \mathrm{v}$ ). When compounds 4 and 7 were excited at $350 \mathrm{~nm}$, the main bands appeared at $383 \mathrm{~nm}$ for 4 and $384 \mathrm{~nm}$ for 7. Similarly, compound 8 was excited at $340 \mathrm{~nm}$, the emission band was seen at $384 \mathrm{~nm}$.

\section{Cell Culture Studies}

Human colorectal cancer cell line (DLD-1) and healthy colon epithelial cell line (CCD-18Co), purchased from the American Type Culture Collection, were cultured in RPMI-1640 and DMEM mediums, respectively, and supplemented with 10\% FBS (ATCC, USA), 1\% pen-strep. The cells were incubated at $37^{\circ} \mathrm{C}$ with $5 \%$ $\mathrm{CO}_{2}$. All standard cell culture laboratory chemicals and reagents were purchased from corning life Sciences (Massachusetts, USA).

\section{Cell Proliferation Assays}

The cell number was calculated by $\mathrm{TC}^{\mathrm{TM}}$ Automated Cell Counter (Bio-Rad, USA), and 1x104 of the DLD1 and CCD-18Co cells were seeded in a 96-well plate incubated for $24 \mathrm{~h}$ at $37^{\circ} \mathrm{C}$ with $5 \% \mathrm{CO}_{2}$. The cells were washed with $10 \mathrm{mM}$ PBS to remove the unattached cell, then treated with the newly synthesized compounds were also diluted with the growth mediums with eight different concentrations of up to 200 $\mu \mathrm{M}$. and incubated for $48 \mathrm{~h}$ at $37^{\circ} \mathrm{C}$ with $5 \% \mathrm{CO}_{2}$. The cells were then washed with $10 \mathrm{mM}$ PBS to remove dead cells and incubated with 10\% Alamar blue reagent, a resazurin-based cell viability dye, for $3 \mathrm{~h}$. Conversion of resazurin to resorufin was spectrophotometrically monitored at 570 and $600 \mathrm{~nm}$ (28). The results were analyzed by GraphPad Prism 8.0 software, and the $\mathrm{IC}_{50}$ values were determined from sigmoidal plots of cell inhibition vs. log compound concentration. 


\section{Bio-Imaging Studies}

To visualize the localization of compounds in DLD- 1 cells, $1 \times 10^{5}$ of the cells were seeded into glass bottom-high quality imaging cell culture micro-Dishes and incubated for $24 \mathrm{~h}$ at $37^{\circ} \mathrm{C}$ with $5 \% \mathrm{CO}_{2}(20)$. The cells were then washed with $10 \mu \mathrm{M}$ PBS and treated with $5 \mu \mathrm{M}$ of the compounds and incubated for 30 min at $37^{\circ} \mathrm{C}$ with $5 \% \mathrm{CO}_{2}$. Following the incubation, the cells were washed with $10 \mu \mathrm{M}$ PBS to remove the excess amount of compound and monitored with ZOE Fluorescent Cell Imager (Bio-Rad, USA).

\section{Results And Discussion}

This study's primary purpose was to design and synthesize new fluorescence anti-tumor calixarene derivatives [4 and 7] (Scheme 1). p-tert-butylcalix[4]arene [1] and the diester [2], dihydrazide [3], phthalimide [5], diaminopropyl [6] derivatives of $p$-tert-butylcalix[4]arenes were synthesized according to published methods $(14,34,13)$. The characterization of the compounds was performed using standard spectroscopic techniques (Fig.S1-17).

For this purpose, the treatment of dihydrazide (3) and diaminopropyl (6) derivative of $p$-tertbutylcalix[4]arene with 4-sulfo-1,8-naphthalic anhydride in $\mathrm{DMF} / \mathrm{H}_{2} \mathrm{O}$ formed 4 and 7 in $80 \%$ and $85 \%$ yields, respectively.

In the FT-IR spectrum of compound 4 , the bands belonging to carbonyl $(\mathrm{C}=0)$ and $0-\mathrm{H}$ groups are observed at $1673 \mathrm{~cm}^{-1}$ 'and $3496 \mathrm{~cm}^{-1}$, respectively, while the bands at 3196,3093 , and $2955 \mathrm{~cm}^{-1}$ are $\mathrm{C}-\mathrm{H}$ and $\mathrm{N}-\mathrm{H}$ belong to groups (Fig.S15). In the ${ }^{1} \mathrm{H}-\mathrm{NMR}$ spectrum of 4, the 4-sulfo-1.8 naphthyl groups' aromatic protons were observed at 7.8 to $9.2 \mathrm{ppm}$. Besides, the peaks of two t-butyl groups of 18 protons were observed at 1.1, and $1.5 \mathrm{ppm}$ indicate that two naphthyl groups are attached to Calix[4]arene (Fig.S7). In the ${ }^{13} \mathrm{C}$-NMR spectrum of compound 4, the peaks at 164.8 and $164.3 \mathrm{ppm}$ indicate the $\mathrm{C}=0$ groups (Fig.S12).

In the FT-IR spectrum of compound 7, the band seen at $1670 \mathrm{~cm}^{-1}$ confirms the imide carbonyl $(C=0)$ group. The bands observed at $3330 \mathrm{~cm}^{-1}, 3045$ and $2955 \mathrm{~cm}^{-1}$ are vibrational bands belonging to $\mathrm{O}-\mathrm{H}$, $\mathrm{N}-\mathrm{H}$, and $\mathrm{C}-\mathrm{H}$ groups (Fig.S16). In the ${ }^{1} \mathrm{H}-\mathrm{NMR}$ spectrum of compound 7, 4-sulfo naphthyl protons were observed at 7.76-7.86 to 9.17-9.2 ppm, while signals for the aromatic protons of calix[4]arene were observed at $7.11 \mathrm{ppm}$. Also, protons belonging to t-butyl groups were seen at 1.1 and $1.16 \mathrm{ppm}$ in this compound (Fig.S10). As seen in the ${ }^{13} \mathrm{C}$-NMR spectrum of compound 7 , the peak appeared at $164.2 \mathrm{ppm}$ confirms the $\mathrm{C}=\mathrm{O}$ group (Fig.S13).

To see the cytotoxic effect of the 4-sulfo-1,8-naphthalimide group before binding to calix[4]arene compound, compound $\mathbf{8}$ was synthesized. In the FT-IR spectrum of compound $\mathbf{8}$, the carbonyl group's band was observed at $1655 \mathrm{~cm}^{-1}$ (Fig.S17). Besides, in the ${ }^{1} \mathrm{H}$-NMR spectrum of $\mathbf{8}$, the signals of aromatic protons between 9.2 and 7.8 ppm and the protons of methyl groups at 2.24 ppm (Fig.S11), as 
well as the appearance of the carbonyl group at 164.2 and $163.5 \mathrm{ppm}$ in the ${ }^{13} \mathrm{C}-\mathrm{NMR}$ spectrum, confirm the compound (Fig.S14).

4 and 7 treatment of human CRC cell lines; DLD-1 significantly suppresses the cell growth in a dosedependent manner (Fig. 1) while the proliferation of healthy colon epithelial cells (CCD-18Co) was not affected with $\mathbf{4}$ and $\mathbf{7}$ treatment (Fig. 1). The $\mathrm{IC}_{50}$ values of $\mathbf{4}$ and $\mathbf{7}$ were calculated as $12.95 \mu \mathrm{M}$ and $16.13 \mu \mathrm{M}$, respectively, on DLD-1 cells. On the other hand, following the treatment of CCD-18Co cells with 4 and 7 , the $\mathrm{IC}_{50}$ values were determined as $508 \mu \mathrm{M}$ and $269 \mu \mathrm{M}$, respectively (Fig. 1). A decrease in cell proliferation started $24 \mathrm{~h}$ after treatment with the compounds. A reduction in the cell number proved that their action on the cancerous cells isn't cytostatic, it is cytotoxic.

Compounds 4 and 7 synthesized in this study showed cytotoxic effects against DLD-1 cells. In contrast, compound $\mathbf{8}$ did not show cytotoxic effects, which can be explained by the fact that compounds $\mathbf{4}$ and $\mathbf{7}$ contain hydrophilic (4-sulfo 1.8 naphthylimide) groups and hydrophobic (calix[4]arene) structures. A similar study was done by Ding et al. They synthesized Calix[n]arene compounds containing hydrophilic and hydrophobic parts by connecting calix[n]arene compounds with $\mathrm{N}, \mathrm{N}$-dimethylaminoethyl groups. These compounds exhibited a highly effective anti-tumor effect, and this effect was explained by the fact that the calix[n]arene compound had both hydrophobic and hydrophilic parts (18). Besides, the fact that it showed very low cytotoxicity in anti-cancer studies performed with compound $\mathbf{8}$, which has a very hydrophilic structure, explains this situation. It is not surprising that the monomeric analog does not show cytotoxicity. In literature, Viola et al. compared calixarenes and monomeric analogs, the anti-cancer properties of different calix[8]arene derivatives bearing the urea group were investigated. The calix[8]arene derivative bearing the N-acetyl-D-glucosamine group inhibited cancer cells' metastasis and proliferation. The monomeric analog of calix[8]arene did not show any anti-cancer effect. This can be explained by the synthesis of the compound in cone conformation and by the cooperative effect of the groups carried by calixarenes (48). Bio-imaging and fluorescence properties of the compounds were examined. From these images given Fig. 2, it is understood that compounds 4, 7, and 8 entered the cell and radiated into the fluorescence emission.

\section{Conclusion}

In conclusion, we designed two new fluorescence calixarene derivatives and examined their cytotoxic properties on DLD-1. Comparing the cytotoxic effects of compounds 4 and 7 on the DLD-1 cell, it was determined that compound $\mathbf{4}$ was more effective than compound $\mathbf{7}$. Besides, when $\mathbf{4}$ and $\mathbf{7}$ were examined in a healthy colon epithelial cell line, it was determined that these compounds did not show any significant cytotoxicity. No significant toxic effect was observed when $\mathrm{N}, \mathrm{N}$-dimethylaminoethyl-1,8naphthalimide derivative (8) was used in the DLD-1 cell line. The increase in cytotoxicity of 4-sulfo-1,8naphthalimide due to binding to the hydrophobic calix[4]arene unite indicates that the calix[4]arene unit plays a vital role in cell death. The bio-imaging study of compounds $\mathbf{4 , 7}$, and $\mathbf{8}$ were performed, and a high fluorescence imaging study of $\mathbf{4}$ and $\mathbf{7}$ were obtained. This study has developed two new selective and cost-effective fluorescent anti-tumor agents and will pave the way for future studies. 


\section{Declarations}

\section{Acknowledgments}

We would like to thank the Research Foundation of Selcuk University (SUBAP-Grant Number: 18201123) for financial support of this work and is Ayse Yildirim's master thesis

Author Contribution A. Yildirim and S. Karakurt performed the research; A. Yildirim designed the experiments and wrote the manuscript. M. Yilmaz supervised the research and helped to draft the manuscript. All authors read and approved the final manuscript.

Funding This study was supported by the Research Foundation of Selcuk University (SUBAP-Grant Number: 18201123).

Data Availability The datasets used and/or analyzed during the current study are available from the corresponding author on reasonable request.

\section{Declarations}

Ethics Approval Not applicable.

Consent to Participate Not applicable.

Consent for Publication All authors have read and approved this version of the article and consented for publication.

Conflict of Interest The authors declare no competing interests.

\section{References}

1. Agur, Z., Arnon, R., \& Schechter, B. (1988). Reduction of cytotoxicity to normal tissues by new regimens of cell-cycle phase-specific drugs. Mathematical Biosciences, 92, 1-15.

2. An, L., Han, L. L., Zheng, Y. G., Peng, X. N., Xue, Y. S., Gu, X. K., Sun, J., \& Yan, C. G. (2016). Synthesis, $\mathrm{X}$-ray crystal structure and anti-tumor activity of calix [n] arene polyhydroxyamine derivatives. European journal of medicinal chemistry, 123, 21-30.

3. An, L., Wang, C., Liu, J. D., Huang, T. H., Han, L. L., Zheng, Y. G., Sun, J., \& Yan, C. G. (2019). Structural Design, Synthesis and Preliminary Biological Evaluation of Novel Dihomooxacalix [4] arene based Anti-tumor Agents. Frontiers in chemistry, 7, 856.

4. An, L., Wang, C., Zheng, Y. G., Liu, J. D., \& Huang, T. H. (2020) Design, synthesis and evaluation of calix [4] arene-based carbonyl amide derivatives with antitumor activities. European Journal of Medicinal Chemistry, 112984.

5. Banerjee, S., Veale, E. B., Phelan, C. M., Murphy, S. A., Tocci, G. M., Gillespie, L. J., Frimannsson, D. O., Kelly, J. M., \& Gunnlaugsson, T. (2013). Recent advances in the development of 1, 8-naphthalimide 
based DNA targeting binders, anticancer and fluorescent cellular imaging agents. Chemical Society Reviews, 42, 1601-1618.

6. Basu, S., Gavert, N., Brabletz, T., \& Ben-Ze'ev, A. (2018). The intestinal stem cell regulating gene ASCL2 is required for L1-mediated colon cancer progression. Cancer Letters, 424, 9-18.

7. Blaskovich, M. A., Lin, Q., Delarue, F. L., Sun, J., Park, H. S., Coppola, D., Hamilton, A. D., \& Sebti, S. M. (2000). Design of GFB-111, a platelet-derived growth factor binding molecule with antiangiogenic and anticancer activity against human tumors in mice. Nature biotechnology, 18, 1065-1070.

8. Brana, M., Castellano, J., Roldan, C., Santos, A., Vazquez, D., \& Jimenez, A. (1980). Synthesis and mode (s) of action of a new series of imide derivatives of 3-nitro-1, 8 naphthalic acid. Cancer chemotherapy and pharmacology, 4, 61-66.

9. Bray, F., Ferlay, J., Soerjomataram, I., Siegel, R. L., Torre, L. A., \& Jemal, A. (2018). Global cancer statistics 2018: Globocan estimates of incidence and mortality worldwide for 36 cancers in 185 countries. CA: a cancer journal for clinicians, 68, 394-424.

10. Cao, M., Chen, H., Chen, D., Xu, Z., Liu, S. H., Chen, X., \& Yin, J. (2016). Naphthalimide-based fluorescent probe for selectively and specifically detecting glutathione in the lysosomes of living cells. Chemical communications, 52, 721-724.

11. Castaldelli, E., Triboni, E. R., \& Demets, G. J.-F. (2011). Self-assembled naphthalenediimide derivative films for light-assisted electrochemical reduction of oxygen. Chemical Communications, 47, 55815583.

12. Chabner, B. A., \& Roberts, T. G. (2005). Chemotherapy and the war on cancer. Nature Reviews Cancer, $5,65-72$.

13. Chrisstoffels, L. A., de Jong, F., Reinhoudt, D. N., Sivelli, S., Gazzola, L., Casnati, A., \& Ungaro, R. (1999). Facilitated transport of hydrophilic salts by mixtures of anion and cation carriers and by ditopic carriers. Journal of the American Chemical Society, 121, 10142-10151.

14. Collins, E. M., McKervey, M. A., Madigan, E., Moran, M. B., Owens, M., Ferguson, G., \& Harris, S. J. (1991). Chemically modified calix [4] arenes. Regioselective synthesis of 1, 3-(distal) derivatives and related compounds. X-Ray crystal structure of a diphenol-dinitrile. Journal of the Chemical Society, Perkin Transactions, 1, 3137-3142.

15. Costanza, M. E., Berry, D., Henderson, I. C., Ratain, M. J., Wu, K., Shapiro, C., Duggan, D., Kalra, J., Berkowitz, I., \& Lyss, A. P. (1995). Amonafide: An active agent in the treatment of previously untreated advanced breast cancer-a cancer and leukemia group B study (Calgb 8642). Clinical cancer research, 1, 699-704.

16. Den Bakker, C., Schaafsma, F., Huirne, J., Consten, E., Stockmann, H., Rodenburg, C., De Klerk, G., Bonjer, H., \& Anema, J. (2018). Cancer survivors' needs during various treatment phases after multimodal treatment for colon cancer-is there a role for a Health? BMC cancer, 18, 1-12.

17. Dhar, S., Singha Roy, S., Rana, D. K., Bhattacharya, S., Bhattacharya, S., \& Bhattacharya, S. C. (2011). Tunable solvatochromic response of newly synthesized antioxidative naphthalimide derivatives: 
intramolecular charge transfer associated with hydrogen bonding effect. The Journal of Physical Chemistry A, 115, 2216-2224.

18. Dings, R. P., Levine, J. I., Brown, S. G., Astorgues-Xerri, L., MacDonald, J. R., Hoye, T. R., Raymond, E., \& Mayo, K. H. (2013). Polycationic calixarene PTX013, a potent cytotoxic agent against tumors and drug resistant cancer. Investigational new drugs, 31, 1142-1150.

19. Duke, R. M., Veale, E. B., Pfeffer, F. M., Kruger, P. E., \& Gunnlaugsson, T. (2010). Colorimetric and fluorescent anion sensors: an overview of recent developments in the use of 1,8-naphthalimidebased chemosensors. Chemical society reviews, 39, 3936-3953.

20. Elcin, S., Deligöz, H., Bhatti, A. A., Oguz, M., Karakurt, S., \& Yilmaz, M. (2016). Synthesis and evaluation of fluorescence properties of $\mathrm{Cu}^{2+}$ selective azocalix [4] arenes and their application in living cell imaging. Sensors and Actuators B: Chemical, 234, 345-352.

21. Fan, P., Wan, L., Shang, Y., Wang, J., Liu, Y., Sun, X., \& Chen, C. (2015). Spectroscopic investigation of the interaction of water-soluble azocalix [4] arenes with bovine serum albumin. Bioorganic chemistry, $58,88-95$.

22. Fu, D., Lu, T., Liu, Y., Wang, Y., Li, F., Wu, Y., Ogden, M., \& Mocerino, M. (2016). Enantioselective Inhibition of human papillomavirus L1 pentamer formation by chiral-proline modified Calix [4] arenes: targeting the protein interface. Chemistry Select, 1, 6243-6243.

23. Gutsche, C. D., Dhawan, B., No, K. H., \& Muthukrishnan, R. (1981). Calixarenes. 4. The synthesis, characterization, and properties of the calixarenes from p-tert-butylphenol. Journal of the American Chemical Society, 103, 3782-3792.

24. Housman, G., Byler, S., Heerboth, S., Lapinska, K., Longacre, M., Snyder, N., \& Sarkar, S. (2014). Drug resistance in cancer: an overview. Cancers, 6, 1769-1792.

25. Joseph, R., \& Rao, C. P. (2011). Ion and molecular recognition by lower rim 1, 3-di-conjugates of calix [4] arene as receptors. Chemical reviews, 111, 4658-4702.

26. Karakurt, S. (2016). Modulatory effects of rutin on the expression of cytochrome P450s and antioxidant enzymes in human hepatoma cells. Acta Pharmaceutica, 66, 491-502.

27. Karakurt, S., Abusoglu, G., \& Arituluk, Z. C. (2020). Comparison of anticarcinogenic properties of Viburnum opulus and its active compound p-coumaric acid on human colorectal carcinoma. Turkish Journal of Biology, 44, 252-263.

28. Karakurt, S., \& Adali, O. (2016) Tannic acid inhibits proliferation, migration, invasion of prostate cancer and modulates drug metabolizing and antioxidant enzymes. Anti-Cancer Agents in Medicinal Chemistry (Formerly Current Medicinal Chemistry-Anti-Cancer Agents), 16, 781-789.

29. Kirilova, E. M., \& Kalnina, I. (2010). 3-isopropyloxy-6-morpholino-2-phenylphenalen-1-one as lipophilic fluorescent probe for lymphocyte investigations. Applied biochemistry and biotechnology, 160, 1744-1751.

30. Krasteva, P. V., Dimitrova, M. D., Georgiev, N. I., \& Bojinov, V. B. (2018). A Novel 1, 8-Naphthalimide Probe for Selective Determination of $\mathrm{Hg}^{2+}$ In A Wide Ph Window (53). Journal of Chemical Technology \& Metallurgy. 
31. Liu, Y.-L., Yang, L., Li, L., Guo, Y.-Q., Pang, X.-X., Li, P., Ye, F., \& Fu, Y. (2019). A New Fluorescent Chemosensor for Cobalt (II) lons in Living Cells Based on 1, 8-Naphthalimide. Molecules, $24,3093$.

32. Livshits, Z., Rao, R. B., \& Smith, S. W. (2014). An approach to chemotherapy-associated toxicity. Emergency Medicine Clinics, 32, 167-203.

33. MacGregor, K. A., Robertson, M. J., Young, K. A., von Kleist, L., Stahlschmidt, W., Whiting, A., Chau, N., Robinson, P. J., Haucke, V., \& McCluskey, A. (2014). Development of 1, 8-naphthalimides as clathrin inhibitors. Journal of Medicinal Chemistry, 57, 131-143.

34. Maity, D., Chakraborty, A., Gunupuru, R., \& Paul, P. (2011). Calix [4] arene based molecular sensors with pyrene as fluoregenic unit: effect of solvent in ion selectivity and colorimetric detection of fluoride. Inorganica Chimica Acta, 372, 126-135.

35. Marshall, M. E., Blumenstein, B., Crawford, E. D., Thompson, I. M., Craig, J. B., Eisenberger, M., \& Ahmann, F. (1994). Phase II trial of amonafide for the treatment of advanced, hormonally refractory carcinoma of the prostate. A Southwest Oncology Group study. American journal of clinical oncology, 17, 514-515.

36. Neri, P., Sessler, J. L., \& Wang, M.-X. (2016). Calixarenes and beyond. ed. Springer.

37. Oguz, M., Gul, A., Karakurt, S., \& Yilmaz, M. (2020). Synthesis and evaluation of the antitumor activity of Calix [4] arene L-proline derivatives. Bioorganic Chemistry, 94, 103207.

38. Olgen, S. (2018). Overview on anticancer drug design and development. Current medicinal chemistry, 25, 1704-1719.

39. Perret, F., Lazar, A. N., \& Coleman, A. W. (2006) Biochemistry of the para-sulfonato-calix [n] arenes. Chemical Communications, 2425-2438.

40. Safi, S., Asfari, Z., Ehret-Sabatier, L., Leroy, M., \& Hagège, A. (2006). Synthesis and characterization of immunogens based on calix [4] arene-crown-6 for the generation of antibodies directed towards cesium ions. Bioconjugate chemistry, 17, 1346-1350.

41. Shahid, M., Chawla, H. M., \& Bhatia, P. (2017). Novel calix [4] arene based metallo-supramolecular complex for recognition of cyanide ions in aqueous medium. Supramolecular Chemistry, 29, 290295.

42. Staneva, D., Makki, M. S., Sobahi, T. R., Bosch, P., Abdel-Rahman, R. M., Asiri, A., \& Grabchev, I. (2015). Synthesis and spectral characterization of a new blue fluorescent tripod for detecting metal cations and protons. Journal of Luminescence, 162, 149-154.

43. Stevenson, K. A., Yen, S. F., Yang, N. C., Boykin, D. W., \& Wilson, W. D. (1984). A substituent constant analysis of the interaction of substituted naphthalene monoimides with DNA. Journal of medicinal chemistry, 27, 1677-1682.

44. Tomczyk, M. D., \& Walczak, K. Z. (2018). I, 8-Naphthalimide based DNA intercalators and anticancer agents. A systematic review from 2007 to 2017. European Journal of Medicinal Chemistry, 159, 393422.

45. Trindade, F. J., Triboni, E. R., Castanheira, B., \& Brochsztain, S. (2015). Color-tunable fluorescence and white light emission from mesoporous organosilicas based on energy transfer from 1, 8- 
naphthalimide hosts to perylenediimide guests. The Journal of Physical Chemistry C, 119, 2698926998.

46. Veesar, I. A., Solangi, I. B., \& Memon, S. (2015). Immobilization of a-amylase onto a calix [4] arene derivative: Evaluation of its enzymatic activity. Bioorganic chemistry, 60, 58-63.

47. Vineis, P., \& Wild, C. P. (2014). Global cancer patterns: causes and prevention. The Lancet, 383, 549557.

48. Viola, S., Merlo, S., Consoli, G. M., Drago, F., Geraci, C., \& Sortino, M. A. (2010). Modulation of C6 glioma cell proliferation by ureido-calix [8] arenes. Pharmacology, 86, 182-188.

49. Xie, L., Cui, J., Qian, X., Xu, Y., Liu, J., \& Xu, R. (2011). 5-Non-amino aromatic substituted naphthalimides as potential antitumor agents: Synthesis via Suzuki reaction, antiproliferative activity, and DNA-binding behavior. Bioorganic \& medicinal chemistry, 19, 961-967.

50. Yildiz, U., \& Coban, B. (2018). Novel naphthalimide derivatives as selective G-quadruplex DNA binders. Applied biochemistry and biotechnology, 186, 547-562.

51. Yilmaz, B., Bayraç, A. T., \& Bayrakci, M. (2020). Evaluation of anticancer activities of novel facile synthesized calix [n] arene sulfonamide analogs. Applied biochemistry and biotechnology, 190, 1484-1497.

52. Zhang, J., Zhang, X., Xiao, H., Li, G., Liu, Y., Li, C., Huang, H., Chen, X., \& Bo, Z. (2016). 1, 8Naphthalimide-based planar small molecular acceptor for organic solar cells. ACS Applied Materials \& Interfaces, 8, 5475-5483.

53. Zhou, P., Yao, J., Hu, G., \& Fang, J. (2016). Naphthalimide scaffold provides versatile platform for selective thiol sensing and protein labeling. ACS Chemical Biology, 11, 1098-1105.

\section{Figures}




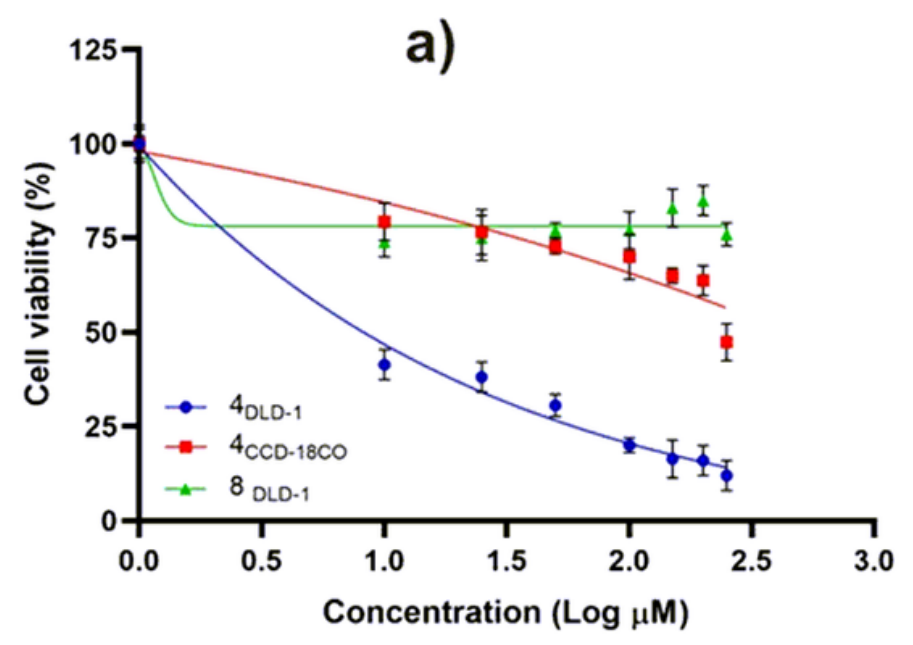

c)

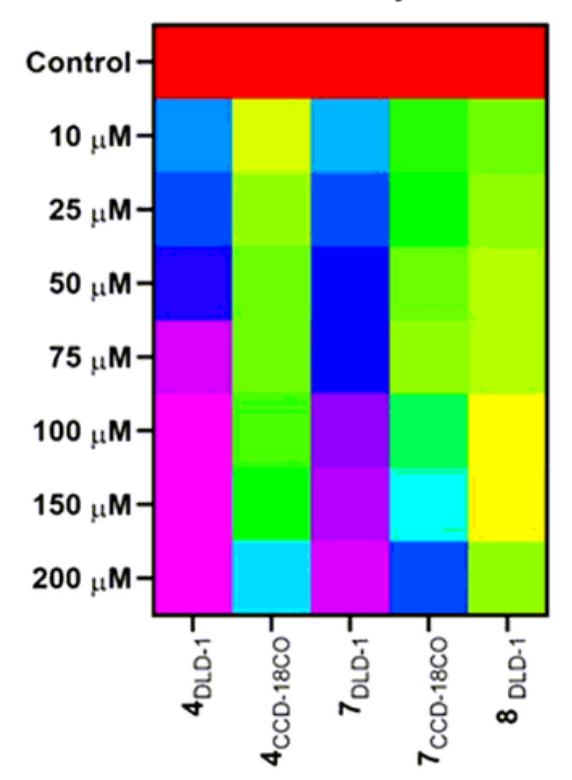

$\square^{100}$

20

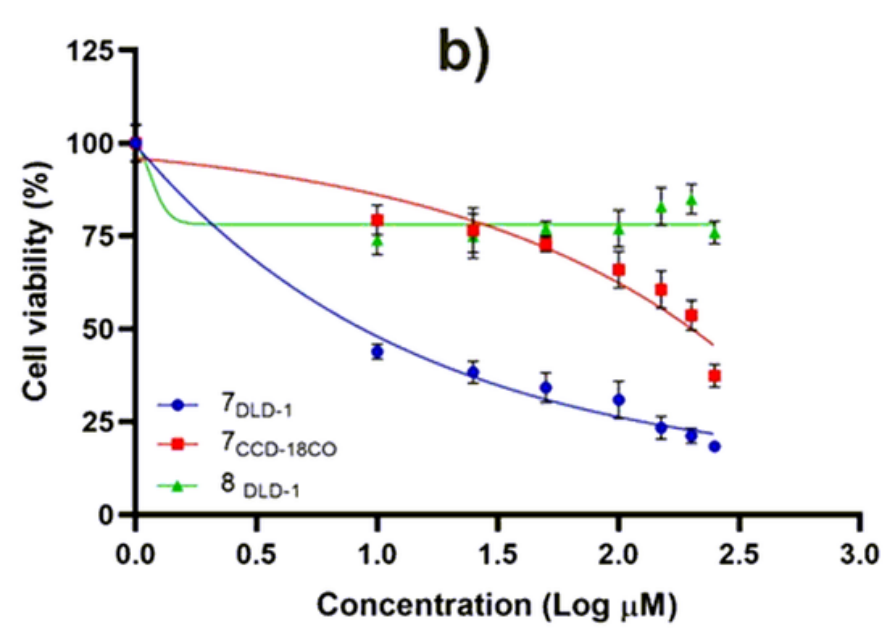

d)

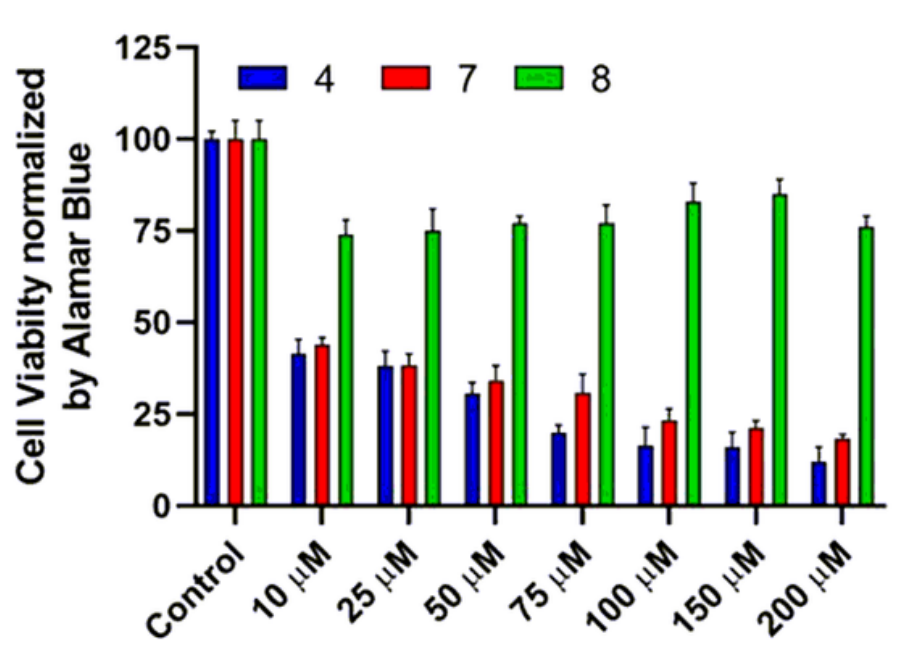

Figure 1

Cytotoxic potential of Compound 4, 7, and 8. (a) Sigmoidal plot of compounds 4 and 8 on DLD-1 and CCD-18Co cells (b) Sigmoidal plot of compounds 7 and 8 on DLD- 1 and CCD-18Co cells (c) Heat map analyses of cell proliferation (d) Comparison of cytotoxic potential of Compound 4,7 and 8. IC50 values were calculated from the ratio of cell inhibition vs. log of compound concentration. The results were expressed as mean \pm SDV of three independent experiments $(n=6)$ 


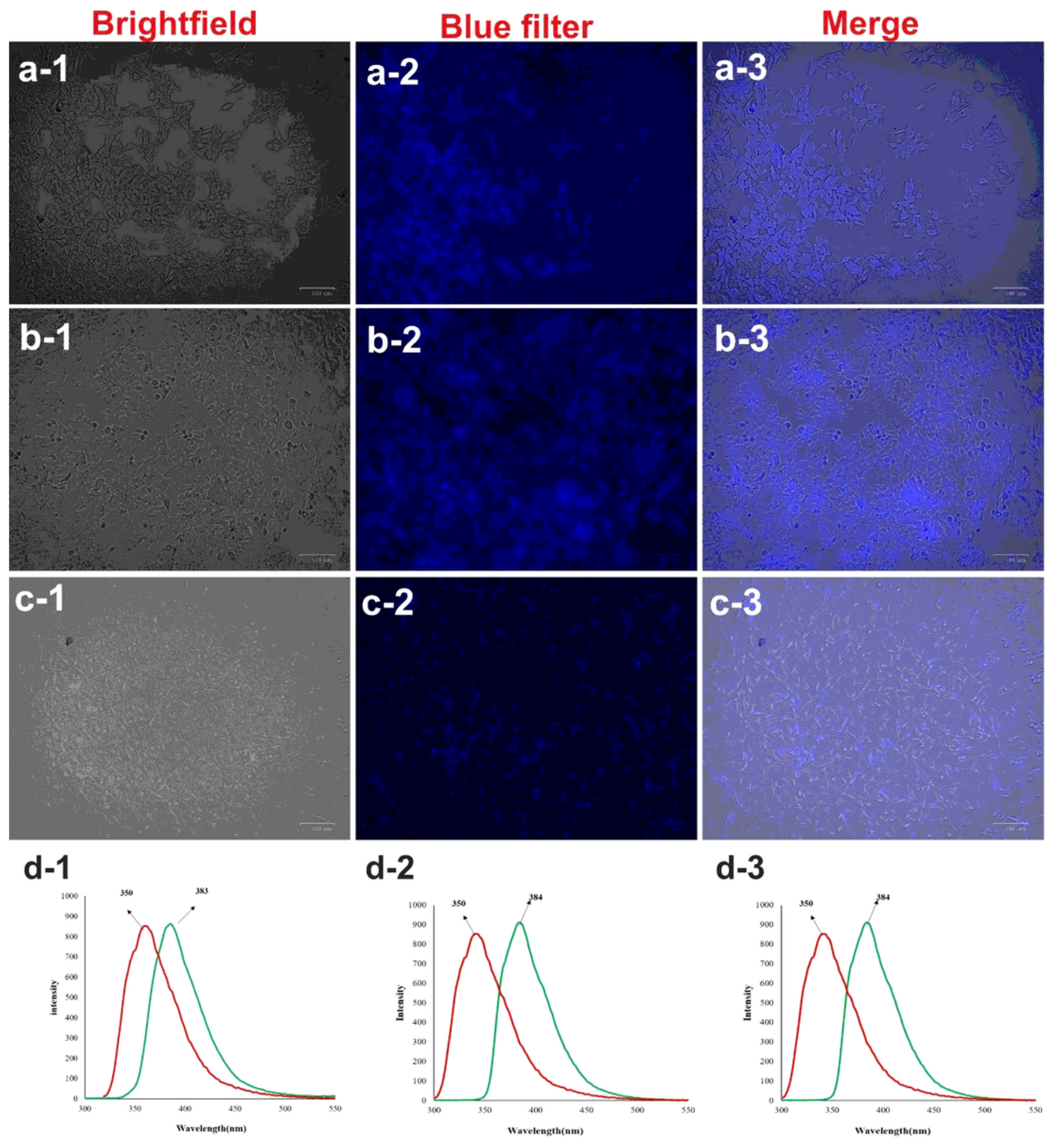

\section{Figure 2}

Bioimaging and Fluorescence properties of the compounds; (a-1, b-1, and c-1) represent the bright field images of compounds 4, 7, and 8, respectively (Left Panel). (a-2, b-2, and c-2) represent the fluorescence field images of compounds 4, 7, and 8, respectively (Middle Panel). (a-3, b-3, and c-3) represent the merge of the fields of compound 4, 7 and 8, respectively, (Right Panel). The cells were treated with the probes (5 $\mu \mathrm{M}$ ) for $30 \mathrm{~min}$. (d-1, d-2, and d-3) represent the fluorescence spectrum of compounds 4,7 , and 8 , 
respectively. Excitation (red) and fluorescence (green) spectra of (1x10-5 M) in DMSO/EtOH. Scalebar=100 $\mu \mathrm{m}, \lambda$ Blue-channel-ex:355/40nm; $\lambda$ Blue-channel-em: 433/36nm.

\section{Supplementary Files}

This is a list of supplementary files associated with this preprint. Click to download.

- Scheme01.png

- Scheme02.png

- Supportinglnfo..docx 